\title{
ケーブル活線下絶縁測定手法と 絶縁抵抗測定誤差についての考察
}

正 員 中 忠 晴(住䉓エンジニアリング)

On-Line Cable Monitoring, its Variation and Measuring Error

Tadaharu Nakayama, Member (Sumiden Engineering Corp.)

Six typical on-line cable monitoring methods were outlined first. In the field, it has become a problem that in some cases measured insulation resistance values contain much error than expected, especially when the outer sheath resistance is lower. This was recognized as a phenomenon due to intrusion of unpredictable and unstable noise voltage " $e n$ " to the measuring system.

The Author presented his extensive investigation results relating to the origins of $e_{n}$, their various aspects, invasion route to the measuring circuit and degrees of influence on the measured resistance values, with the aid of many illustrations and the newly derived numerical formulas which serve as the indexes to tell practicability of each method. Also suggested that all the methods shall be categorized into 3 groups, (A) to (C), according to their extent of measuring error.

Finally, the Author presented and recommended the use of new techniques to reduce $e_{n}$ effects, with the adoption of (B) group methods because of their good practicability.

キーワード：CVケーブル、活線診断、苜流重畳法、雑音電压、地電流打消し、接点接触不良

\section{1. まえがき}

高圧電力ケーブルの絶縁劣化の指標である絶縁爵絶縁抵 抗を、交流高圧に重畳した直流の低信号電圧を用いて活線 下で測定する、というアイデアが実用化されてからはや20 年近くになる。(1)(2)

本手法は一般に直流重曽法と称されているものであるが、 この開発過程で現実に製品化または確定手法として実用化 されたもの、実験的に試みられたもの、紙上検討の域にす ざ好の等々をあらためて振り返ってみると、十指に余る バリ工イションが存在する。本論文ではその中の代表的な 6つの手法についてそのあらましをまず紹介して、諸氏の御 参考に供することとする。

つぎに、現実にフイールドで測定した時に直面したのは、 測定系人侵入する不定雑音電压 $e_{n}$ のために絶縁抵抗測定值 に大きい䛊差を生ずるという問題であった。これは防食層 絶縁抵抗值が低くなると絶縁層絶縁抵抗值が低く测定され ることがあると、一般に解勫されている現象である。

この不定雑音電压enについて、それがどのような発生原 因のもので、如何にして測定系に侵入し、どのような形で 絶縁抵抗測定值に誤差を導入しているのかということを考 察した結果を報告するのが本論文の目的とするところであ
る。

不定雑音電圧 $e n$ の大小が絶縁抵抗測定誤差におよはす影 響の程度は数式的に解析され、その結果として各手法は3つ のグループに分けられることが判った。実用性のあるのは その内の1グループのみである。

最後に、このような絶縁抵抗測定誤差の導入をできるだ け回避するための、現実的な手段を紹介する。

\section{2. 代表的6手法の紹介}

〈2.1〉活線下絶縁抵抗測定の基本概念，測定対象とす る項目は、次の3つである。

個々のケーブルごとの絶縁層絶縁抵抗 $R$ " 防食層絶縁抵抗，Rs

高圧系統全体の系統絶縁抵抗 $R_{B}$

上記を測定するために、直流信号電圧（通常 $+50 \mathrm{~V} ）$ を高 圧系統の接地機器の中性点を通して高圧導体と大地間に注 入するのであるが、これが不必要な手法もある。系統絶緣 抵抗 $R_{B}$ は注入電流を読むことで知ることができる。

直流信号電圧の印加前に、遮へい端と大地間に設けた測 定装置（多くはAmp.付きのDVM）の検出抵抗にあらわれる 電圧eは、測定に誤差を与えるものとして積極的に“地電 流打消し手段”により零化をはかるか、微少な值に低下さ 
せてその值を記録し、ついで直流信号電圧 $E$ を印加して再び 検出抵抗にあらわれる電圧 $\boldsymbol{e}_{2}$ を測定し、直示または計算に より絶縁層絶縁抵抗值を得ることができる。このような“地 電流打消し手段”の具備は一応必須条件であるが、なかに はこれを持たない手法もある。

補助測定電源として遮へい端と大地間に別の直流電源を 必要とする手法もある。その目的の多くは地電流打消しの ため、または防食層絶縁抵抗測定のためである。図1に一般 的な測定回路概念図を用語の定義と共に示す。

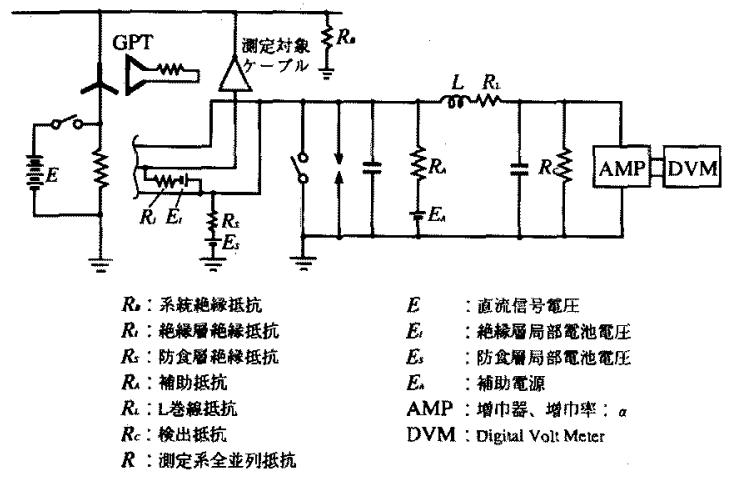

図1 ケーブル活線下緦縁測定の概念図

Fig.1. Conceptual diagram of on-line cable insulation measuring

〈2·2〉代表的6手法一覧表1に、本論文で紹介する手 法一臨を示す。

表1 代表的6手法

Table 1. Typical 6 methods

\begin{tabular}{|c|c|c|c|}
\hline 名 称 & 測定項目 & 測定方式 & 信号電压印加方式 \\
\hline Null電流法 & $R, R_{B}$ & 零位法十偏位法 & On時、Off時の2段階 \\
\hline Null電压法 & $R_{l} R_{B}$ & 零位法 & On時，Off時の2段階 \\
\hline 2電圧法 & $R_{I} R_{s}$ & 偏位法 & 印加不必要またはOn緌続 \\
\hline 3電圧法 & $R_{I} R_{S} R_{B}$ & 偏位法 & On時、Off時の2段階 \\
\hline 4電圧法 & $R / R s$ & 偏位法 & 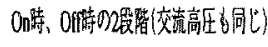 \\
\hline 6電圧法 & $R_{I} R_{s} R_{B}$ & 偏位法 & On時、Off時の2段階 \\
\hline
\end{tabular}

〈2·3〉各手法の解説

(i) Null電流法 （図2）信号電圧印加前に検出抵抗 $R_{C}$ に流れる電流を、対向起電力 $E_{G}$ を調整して打消す。または 零に近く低減してRcの両端の電圧 $e_{0}\left(\right.$ 增幅後 $\left.E_{0}{ }^{\prime \prime \prime}\right)$ を読む。

この状態で $E_{G}$ はこのまとして信号電圧 $E$ を印加し、 $R_{C}$ の雨端の電圧 $e_{I}$ (増幅後 $E_{l}{ }^{\prime \prime \prime}$ ) を読む。

$R_{A}$ はこの場合、測定回路時定数調整用である。

$E_{G}$ の挿入位置は增幅器の前段のみと限らず、中段または 出力段の場合もある。それらの場合はいわゆる地電流 $(R c$ に流入する雑音電流）は実は打消されずに残留する。

（ii） Null電圧法（図3）E印加前にRcに生ずる電圧を

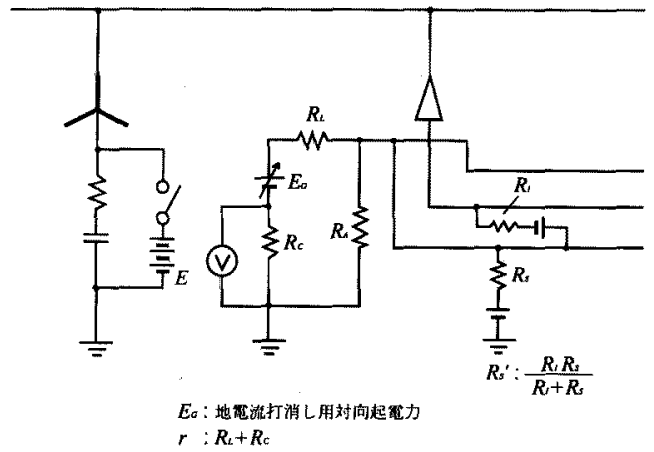

図2 Null電流法

Fig.2. Null current method

零ならしめるよう、標準直流信号電圧発生装置の出力電圧 $E_{G}$ を調整し、その値 $E_{G}$ を読む。ついでEを印加し、再びRc に生ずる電圧を零ならしめるよう調整した結果の出力電圧 $E_{G 2}$ 読む。このように2回遮へい端対大地霓圧の零化を行 なうが、地電流は打消されることなく逆に最大值を保つ。

(VはDigital volt meterであるが、その電圧分解能が零でな

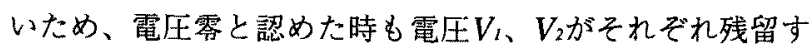
る。

直列抵抗RGはお扔きければ感度が増大するが、测定回路 時定数の増加を招き、 $E_{\sigma}$ の所要值の増加も要求されること になる。地電流の大部分がこれを通るからである。

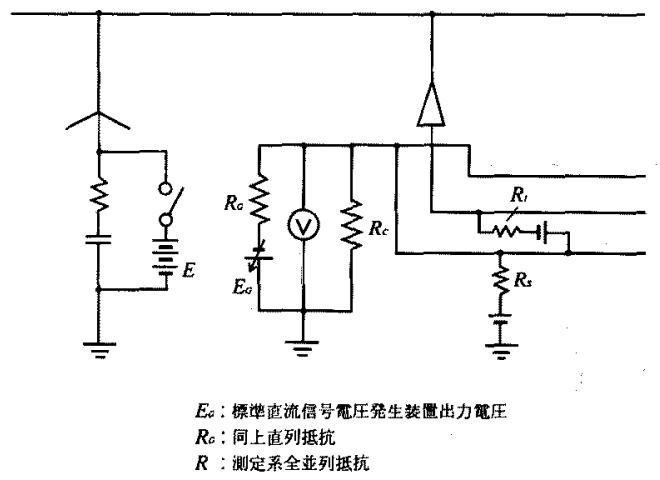

図3 Null電压法

Fig.3. Null voltage method

（iii） 2電圧法（図4）直流信号電压Eの準備を必要と しない。したがって高圧部分に接近する必要もない。貫通 水トリーを生したCVケーブルの絶縁層内部に発生する直流 起電力 $E_{l}$ をEの代わりに用いているのである。Eについては 後でふれる。

異なる抵抗値のRIとR2とを切替え、それぞれの場合の電 压降下 $e_{、} 、 e_{2}$ を読むだけで、RとRsとを求め得る理であるが、 地電流打消しがないので防食層局部電池電圧 $E_{s}$ の影響を強 く受けて、R、良好のケーブルを絶縁不良と誤認する伦険性 が高い。故にチーブル遮へい端から内部を見たときの見か 


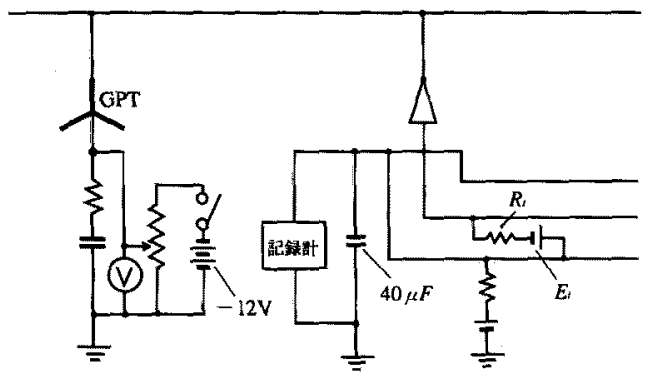

図8 絶縁層局部電池電圧 $E_{l}$ の観測

Fig.8. An Observation of $E_{r}$ generated in the faulty cable insulation

下測定で $R_{I}=2 \mathrm{M} \Omega$ 以下、 $R_{s}=0.18 \mathrm{M} \Omega$ と測定された水卜リ 一劣化CVケーブルである。遮へい端と大地間に $40 \mu \mathrm{F}$ のコ ンデンサを挿入し、その充電電圧を内部抵抗 $2 \mathrm{M} \Omega$ の直流記 録電圧計で測定した。その様相を図9に示す。

GPT側からの電圧印加無しでまず $+6 \mathrm{~V}$ も飽和充電電压 が得られた。これは後述の如く防食層局部電池電圧 $E$ 名から は決して期待できない大きな電圧である。GPT側からー10V を印加すると、記録計指示電圧は低下を開始し $-0.8 \mathrm{~V}$ に達 した。印加電圧を一5Vとすると再び+極性に転じた。零レ ベルの通過はどの方向でも極めてスムースであった。これ より絶縁層内部の起電力は $10 \mathrm{~V} に$ 近いがそれ以下であるこ とが判る。

このような現象は空間電荷などで説明できるものではな く、導体から遮へいまで貫通した自由電子の通過を確保す るパスが存在し、また自由電子の連続供給があるものと解 䣋しなければならない。

この他の観則例も総合して3KV CVケーブルのE值は9V (6KV の場合10Vただし参考值）という值を筆者は採用しているが、 10KV CVケーブルでは17〜20Vを観測したことがある。電 圧極性は遮へい側が十とは限らずーの場合もある。

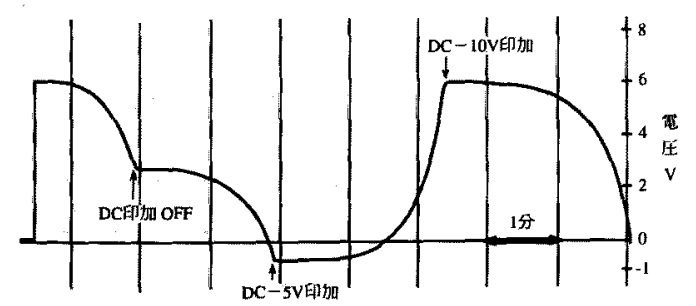

図9 遮へい端電圧の推移（図8の字験結果）

Fig.9. A tansition of the sheath voltage in the experiment Fig 8

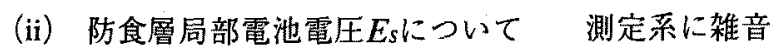
電流を流す起電流能要因としては、E起因のものより压倒 的にこのEs起因の方が大きく、またその発生頻度も大であ ることが経験的に判っている。Es値と極性の分布は図10に 示す如くである。

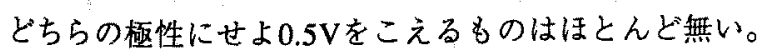

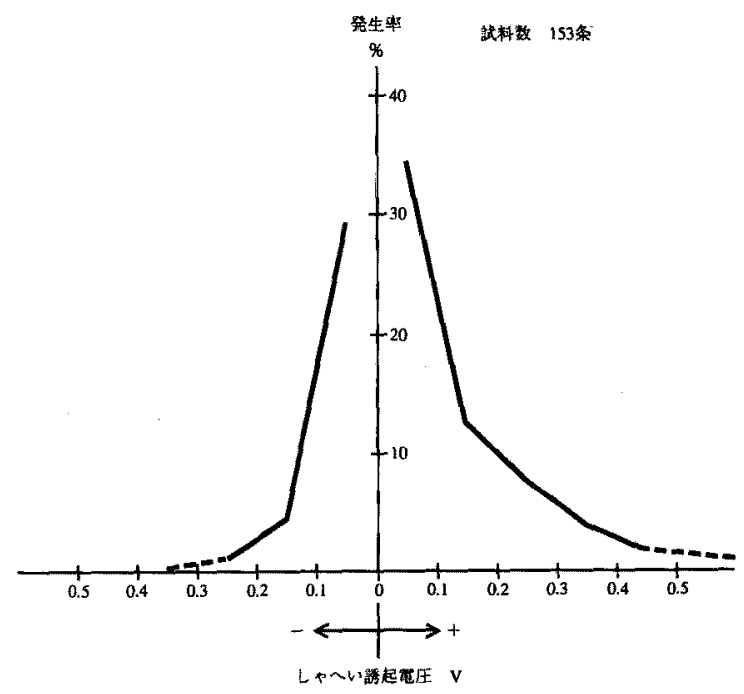

図10 防食層局部電池の極性および電圧値の発生分布

Fig.10. Polarity and voltage of local cell $E_{s}$, statistical investigation

この集計からは外しているが、まれに1Vをこえる（それも いきなり数 $\mathrm{V}$ 観測する）場合はE起因のものである。

防食層局部電池を構成するケーブル側の電極材は、銅、 カーボンであり、他方の電極構成材は状況により様々であ るが、銅、鉄、アルミ、亜鉛等であろう。大半が銅に対し てマイナスの電位を持ち、その電位差は最大で1Vと見られる。

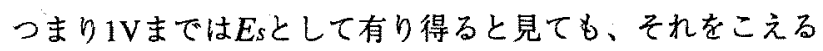
電圧が遮へい端大地間で観測されたら、Eが発生している、 すなわち水トリーによる絶縁不良ケーブルであると認識で きることになる。

\section{3. 絶縁抵抗測定誤差についての考察}

〈3.1〉防食層絶縁抵抗 $R_{s} の$ 低下が絶縁層䋓縁抵抗 $R /$ 測定 值に影響する現象極端な例として図11に、一端が屋外 露出エレファント端末になっていて、その分岐銅管縁切り 絶縁部に雨滴が侵入すると防食層絶縁抵抗が低下する、

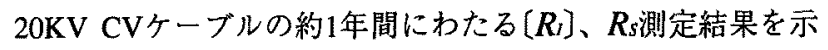
す。

本測定は 3 電圧法で得られたもので、電圧計分解能は $0.01 \mathrm{mV}$ ののを用いているので、理論的な $\left[R_{I}\right]: R s$ エレイション結果は図12に示す如きものでなければならぬ。 すなわち例えRsが $0.1 \mathrm{M} \Omega て ゙ あ っ て も 10 万 \mathrm{M} \Omega の R /$ 充分に 測定されるべきものである。しかるに図11に示す如き状況 となり、 $R_{s}=0.1 \mathrm{M} \Omega$ ではわずか $1000 \mathrm{M} \Omega$ 程度の $[R]$ 值とし て測定されている。一方では $R_{s} か ゙$ 低くても $[R] か ゙ 10 万 \mathrm{M} \Omega$ 以上と測定される場合もあることが示されている。どうし てこのようなことが起り得るのかを以下に検討する。

〈3.2〉上記現象が発生する原因〈3.1〉に示したような 現象が発生する原因は、結論的にいうと、地電流打消し手 段では排除できない不定雑音電圧e $n$ が測定系に侵入するか らである。安定した雑音電圧であるならそれがたとえ1Vと 


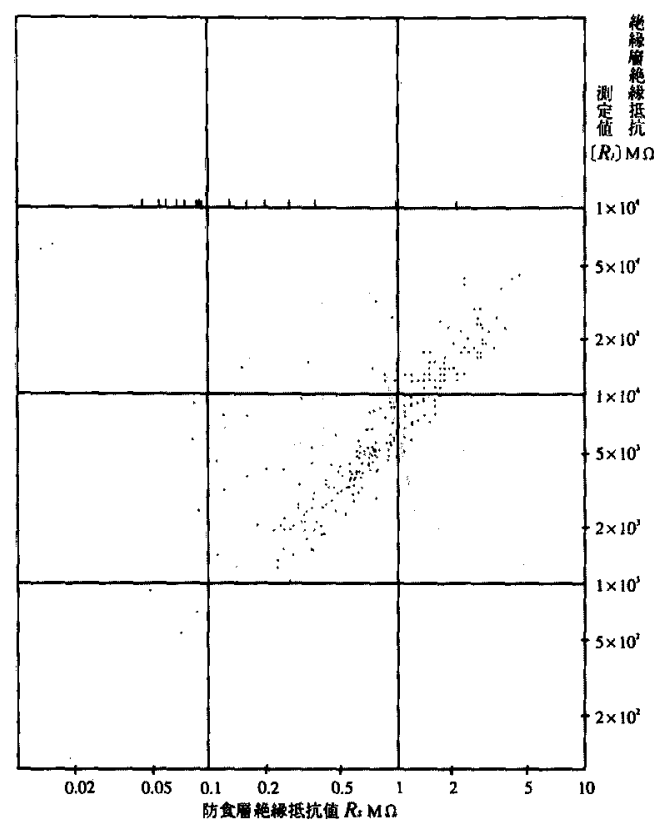

図11〔R]：Rs関係測定例

Fig.11. $\left[R_{I}\right]$ vs. $R s$ relationship investigated on a $22 \mathrm{kV}$ CVT cable

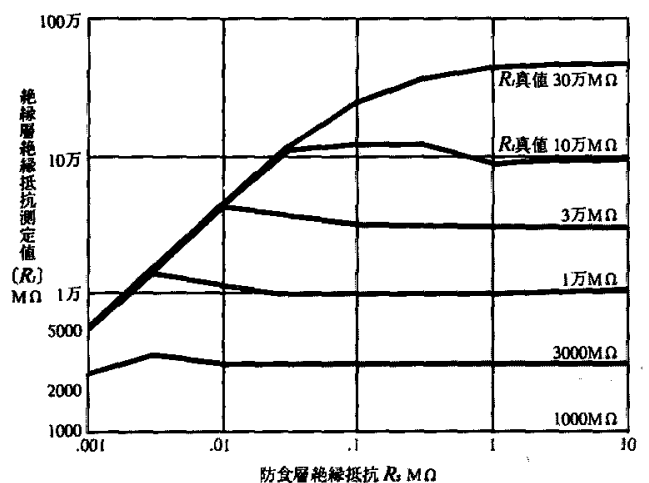

図12 3電圧法における理論的 $[R]: R s$ 関係曲線

Fig.12. Theoretical relationship between $[R]$ and $R s$, 3 voltage method

いうような大きな值であっても、地電流打消し手段により 物理的に、または計算の過程で数式的に減算処理されるので、 別に問題とならない。問題となるのは信号電圧印加前に動 作していた雑音電圧En，と、信号電圧印加後に変化した雑音 電压 $E n_{2}$ との差電圧 $e_{n}=E n_{2}-E n$ であり、 $e_{n}$ 圢大概の場 合その值を予測したり実測したりすることのできない性質 のものである。

さらにこの現象を拡大する要因が $K$ という比例定数であ ることが数式検討の結果判った。 $K$ は絶縁層絶縁抵抗 $R / の 、$ 防食層絶縁抵抗Rsに対する比である。R，測定に誤差を与え る実効的な要因は、 $e_{n}$ 単体ではなく、Kenとして $K$ 倍に增 幅される。故に同じR，同じ $e_{n}$ に対して防食層絶縁抵抗 $R s$ 方 低下するほどR測定值は大きく影響される。同じRs同じ $e_{n}$
であればRが高いほど影響度が大きくなる。

〈3.3〉不定雑音電圧enの侵入するルート enはどのよう な場合にどこへ侵入するのかを検討すると、雑音電圧発生 源の如何を問わず、次の如き $2 つ の$ 代表的ケースをあげられ る。

（i）防食層絶縁抵抗 $R_{s} に$ 直列に侵入する場合（図13）

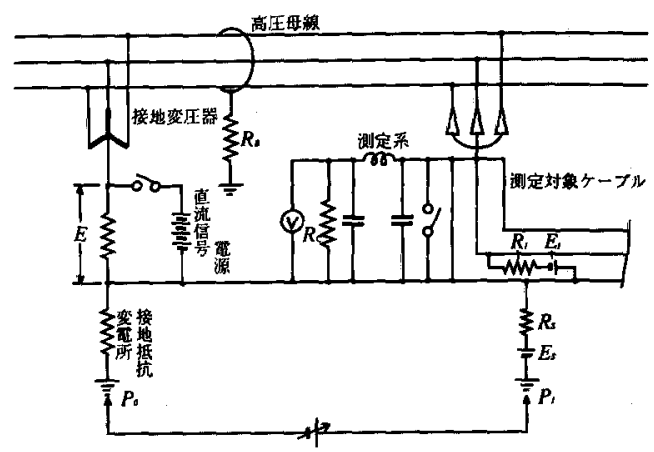

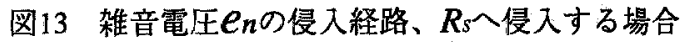

Fig.13. $e_{n}$, Intruded into $R_{s}$ branch, $R s$ falls outside $\mathrm{S} / \mathrm{S}$

高圧系統接地機器扔よび直流信号電源の存在する変電所 内で、ここから送り出されるケーブルを測定する場合で、 防食層絶縁不良箇所は変電所外に存在するという最も普通 のケースである。

$e_{n}$ 発生源の主たるものは

変動する $E_{s}$

変動する変電所接地電位

$P_{0} 、 P_{1}$ 間の変動電流

であって、E,やEsそのものではない。またその発生期間名 直流信号電圧 $E$ の印加に同期するものもあれば、無関係の ものもある。

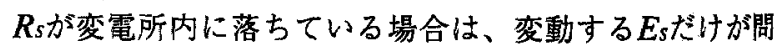
題となる。

（ii）検出抵抗 $R c k$ 直列に侵入する場合（図14）

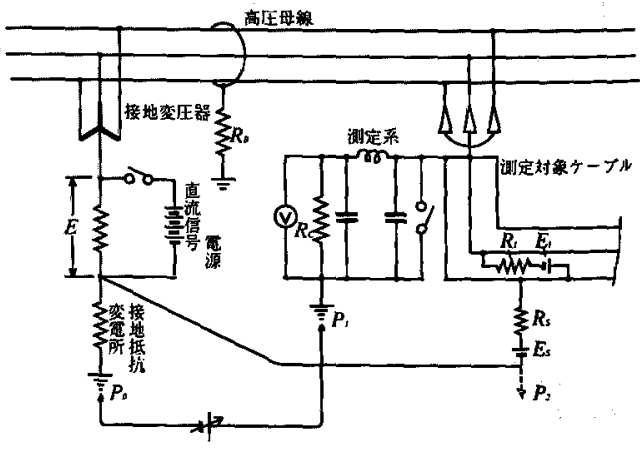

図14 雑音電圧 $e_{n}$ の侵入経路、 $R_{c}$ 一侵入する場合

Fig.14. en, Intruded into $R c$ branch, $R$ s falls inside $\mathrm{S} / \mathrm{S}$ 
高压系統接地機器および直流信号電源の存在する変電所 内にRsが落ちているが、ケーブル端末は変電所外にあって、 したがい測定は変電所外で行なっているケースで余り多く ない。

$e_{n}$ 発生源の主たるものは(i)の場合と同じく

変動する $E$

変動する変電所接地電位

$P_{0} 、 P_{l}$ 間の変動電流

である。Rsが変電所外で $P_{2}$ 点に落ちていれば、変動する $E_{s}$ と、 $P_{\text {小 }} P_{2}$ 間の変動電流だけが問題となる。

〈3.4〉不定雑音電圧en発生の諸様相 発生源ごとにど のような様相のenが発生しているのかを調査した例を以下 に示市。

（i）大地を迷走する直流電流によるものこの場合の 発生源は直流電鉄のレール漏洩電流、外部電源防食装置に よる大地電流等で、前者の例を図15に示す。

これは神戸市内のある変電所の接地母線と、变電所フェ ンスより $20 \mathrm{~m}$ 離れた地点間の電位差を測ったもので、日中 は30mVに達するenが、深夜は $2 \mathrm{mV}$ 程度に収まっており、 この地帯に多数集中している直流電鉄起因のものである。
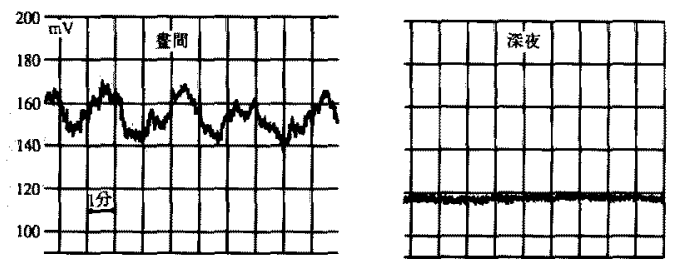

図15 大地迷走直流電流に起因する $e_{n}$

Fig.15. Noise voltage due to adjacent electric railroads

（i）防食層局部電池の電圧変動によるもの 図11に示 したケーブルの例で、わざと変電所外接地を採用して、遮 へい端末との間で3電圧法で測定中の電圧変動状況を示す。 この時のRs值は $0.11 \mathrm{M} \Omega$ 、検出抵抗 $R c$ 值は $100 \mathrm{k} \Omega$ である。 $10 \mathrm{mV}$ 程度の不安定な電圧変動が観測されているが、天候が 回復すると平坦となる。

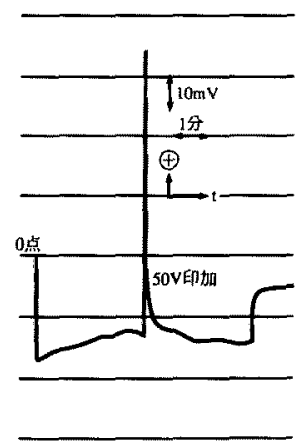

図16 遮へい端対大地電圧の $E_{s}$ 変動を 起因とする不安定性

Fig.16. Fluctuation of sheath voltage observed on the cable shown in Fig.11. (iii) 変電所接地電位の変動によるもの変電所内に存 在し、変電所外の急荷に電力を供給している直流電源があ って、その大地漏洩電流が変電所接地抵抗を通じて電源に 杘るとき、その電流值が不安定であるのでそれに応じた変 電所接地電位变動を生ずる。

その1例を某社 $3 \mathrm{kV}$ 変電所での実測例として図17k示す。 この場合 $e_{n}$ は $200 \mathrm{mV}$ 以上にも達しているが、これは例外的 に大きな值で、通常汁数十 $\mathrm{mVである。}$

直流電源が無ければ一般には5mV以下の変動で、問題は 緩和される。

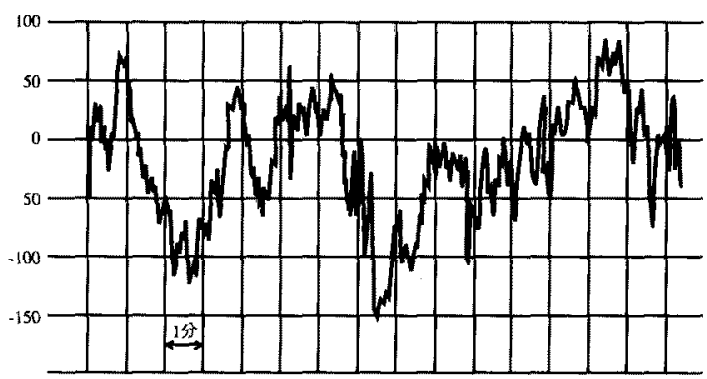

図17 変電所接地電位の変動例

Fig.17. Fluctuation of S/S grounding potential

(iv) 直流信号電圧印加に同期して発生する変電所電位の 偏位これは変電所外のどこかに対大地直流絶緣処置の 施していない接地機器が残存していながら、直流重冨法を 強行するような場合に発生するが、系統絶縁抵抗 $R_{\boldsymbol{B}}$ が極端 に低い場合も同じである。

変電所内に設置した直流信号電源から電圧 $E$ を高圧系統 に注入すると、 $E / R_{B}$ なる漏洩電流と変電所接地抵抗の積 から成る電圧値だけ、変電所電位が印加前の值から偏位す る。Eを切ると元へもどる。図18にその1例を示す。

$E / R_{B}$ が $0.31 \mathrm{~A}$ も流れているのに偏位は $30 \mathrm{mV}$ 程度である から、変電所接地抵抗は $0.1 \Omega$ と極めて低いのか、または変 電所外にとった接地がまだ変電所接地電位変動の影響下に あるのであろう。

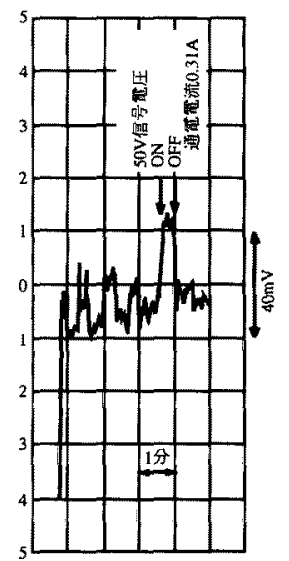

図18 直流信号電圧印加に同期した変電所電位の偏位 Fig.18. Synchronized displacement of S/S grounding petential 
〈3.5〉緦縁抵抗測定值におよぼす $e_{n}$ の影響の数式的解析 各測定手法ごとに、 $e_{n}$ がRに侵入した場合、Rcに侵入し た場合につき、真のRIを求如得る新しい計算式の誘導をま ず行った。今まで実用的に用いて来たR，計算式には $e_{n}$ の項 が無い。新計算式上で $e_{n}=0$ と扔くと従来式と同じ形となり、 実際上これしか使うことはできない。これを実用式と称し、 実用式で計算した絶緑抵抗值を[RI]とし、真值 $R$ に対する 比を $\beta$ とすると、 $\beta$ 值は $e_{n} 、 R 、 R s$ を設定すれば $[R]$ を求 めなくても直接計算で求めることができ、各手法のenの影 響の程度の比較を行なうのに便利である。故に $\beta$ の計算式 若尊出した。

結果として得られた計算式を表2に示す。ただし煩雑をさ

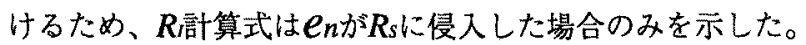
実用式ではenがどの程度の大きさでどこに侵入しているの かは、元より問うところではない。 $\beta$ 計算式のみ $e_{n}$ 侵入箇 所に応じて2つを示した。

各式の誘導詳細については割愛した。

表 $2 に$ 示された $\beta$ 計算式から、各手法は次の3つのグルー プに分けられることが判った。

(A) $e_{n}$ の影響をほとんど受けないグループ 4電压法 6電圧法

(B) Kenの形で影響を受けるグループ

Null電流法Ｎｕll電圧法３電压法

(C) $e n$ のみならず $K E s$ や $E_{l}$ の影響を受けるグループ 2電圧法

(B)と(C)のグループにつき $\left[R_{I}\right]$ とRsの関係をシミュレイシ ヨンした結果を図19捛よび図20に示す。曲線は $\beta$ 計算式に
のっとったもの、黒丸点は $e_{n}=+10 \mathrm{mV}$ 場合の $[R]$ 計算結 果を示す。

どちらもenはRsに侵入した場合のみを扱っている。enが Rck侵入した場合は、異極性の $n$ nがRsに侵入した場合とほ とんど同じであるので省略した。

(B)のグループにくらべて(C)のダループは極めて成續が悪 い。これはシミュレイション条件として $E_{I}=9 \mathrm{~V} 、 E_{s}=0.2 \mathrm{~V}$ が設定されているけれども、(B)のグループではこれらは打 消されてenの影響のみが残るのに対し、(C)のグループでは 打消しが無いうえに、EsまでK倍されて影響するからであ る。

(A)のグループであるが、4電圧法は短時間の交流停電を要 することが致命傷となって実用性が無い。

6電圧法について実際にフィールドで実験してみると、検 出電圧の変動が激しくてこれも奉用にならないことが判っ た。

したがって理想的に見える(A)のグループはアイデア倒れ で実用価值が無く、(C)のグループは絶緑良好のケーブルを 絶縁不良と誤認する危険性があり、結局(B)のグループのみ がKenの形で影響を受けはするが、後に述べる諸手段の助 力を得て実用になる方式であることが明らかとなった。

\section{4. 絶縁抵抗測定誤差の導入を避ける手段}

前述の如く、不定雑音電圧 $\boldsymbol{e}_{n}$ が測定系に侵入し、絶縁抵 抗測定に誤差を与える現象が解明されたが、さて影響をで きるだけ排除するにはどうすれば良いのかという設問に対 しては以下に示す如き諸手段を提供する。

表2 $R 、[R] 、 \beta$ 計算式

Table 2 Calculation formulas for $R_{J},\left[R_{I}\right] \& R_{S}$

\begin{tabular}{|c|c|c|c|c|}
\hline \multirow{2}{*}{ 手法 } & \multirow{2}{*}{$R$ 䛠算式 $\left(e_{n}\right.$ 折込み $)$} & \multirow{2}{*}{$R_{I}$} 計算実用式 & \multicolumn{2}{|c|}{$\beta=\left[R_{I}\right] / R_{I}$ 計算式 } \\
\hline & & & $e_{n} 、 R_{s}$ L侵入 & $e_{n} 、 R c k$ 侵入 \\
\hline \multirow{2}{*}{$\begin{array}{l}\text { Null } \\
\text { 㴗流法 }\end{array}$} & $R_{i}=-\quad a R_{c} R_{s}^{\prime}\left(E-e_{n}\right)$ & \multirow{2}{*}{$\left(R_{1}\right]=\frac{{ }_{a} R_{e} R_{j}^{\prime} E}{\left(E_{i}^{\prime \prime \prime}-E_{0}{ }^{\prime \prime}\right)\left(R_{s}^{\prime}+r\right)}$} & \multirow{2}{*}{$\beta=\frac{E}{E+K e_{n}}$} & \multirow{2}{*}{$\beta=\frac{E}{E-\ln (1+K)}$} \\
\hline & $\left(E_{1}^{\prime \prime \prime}-E_{0}^{\prime \prime \prime}\right)\left(R_{s}^{\prime}+r\right)-e_{n a} R_{c}$ & & & \\
\hline \multirow{2}{*}{$\begin{array}{l}\text { Null } \\
\text { 電任法 }\end{array}$} & $R_{1}=-\quad R_{1}^{\prime} R_{G}\left(E-e_{n}\right)$ & \multirow{2}{*}[R]{$=\frac{R_{G} E}{-\left(E_{a_{2}}-E_{a_{1}}\right)}$} & \multirow{2}{*}{$\beta \doteqdot \frac{E}{E+K e_{n}}$} & \multirow{2}{*}{$\beta \doteqdot \frac{E}{E-e_{n}(1+K)}$} \\
\hline & $R_{t}\left(V_{2}-V_{1}\right) R_{s}^{\prime} / R-R_{s}^{\prime}\left(E_{\theta t}-E_{0 i}\right)-e_{n} R_{i}$ & & & \\
\hline \multirow{2}{*}{ 2電压法 } & $R_{1}=$ & \multirow{2}{*}{$(R)=\frac{r_{1} r_{i}\left(e_{i}-e_{i}\right) E_{i}}{e_{1} e_{i}\left(r_{i}-r_{i}\right)}$} & \multirow{2}{*}{$\beta=\frac{E_{i}}{E_{i}+K\left(E_{s}+e_{n}\right)}$} & \multirow{2}{*}{$\beta \doteqdot \frac{E_{i}}{E_{i}-e_{n}+K\left(E_{-}-e_{n}\right)}$} \\
\hline & $e_{1} e_{2} R_{1}\left(r_{1}-r_{2}\right)+E_{s}\left(r_{1} r_{2}\left(e_{1}-e_{2}\right)+R_{1}\left(e_{1} r_{2}-e_{2} r_{1}\right)\right]+e_{n} e_{i} r_{2}\left(r_{1}+R_{1}\right)$ & & & \\
\hline \multirow{2}{*}{ 3電压跮 } & $R_{4}=-R_{1} r_{1} r_{2}\left\langle e_{1}-e_{2}\right\}\left(E-e_{4}\right)$ & \multirow{2}{*}[R_{1}]{$=\frac{r_{1} r_{2}\left(e_{1}-e_{2}\right) E}{e_{2}\left(e_{1}-e_{0}\right)\left(r_{1}-r_{2}\right)}$} & \multirow{2}{*}{$\beta=\frac{E}{E+K e_{n}}$} & \multirow{2}{*}{$\beta=\frac{E}{E-e_{n}(1+K)}$} \\
\hline & $e_{2} R_{n}\left(r_{1}-r_{2}\right)\left(e_{1}-e_{0}\right)+e_{n}\left[R_{1}\left(e_{1} r_{2}-e_{2} r_{1}\right)+r_{1} r_{2}\left(e_{1}-e_{2}\right)\right]$ & & & \\
\hline \multirow{2}{*}{ 4電压法 } & $R=\frac{r_{1}\left(-E+e_{n}-e_{2}+e_{1}\right)\left(e_{1}-e_{3}+E\right)}{2}$ & \multirow{2}{*}{$\left(R_{i}\right)=\frac{r_{1}\left(-E-e_{2}+e_{1}\right)\left(e_{1}-e_{3}+E\right)}{-E\left(e_{2}-e_{1}-e_{1}+e_{3}\right)}$} & \multirow{2}{*}{$\beta \doteqdot 1$} & \multirow{2}{*}{$\beta \div 1$} \\
\hline & $K=\frac{\left(-E+e_{n}\right)\left(e_{2}-e_{1}-e_{1}+e_{3}\right)}{(1)}$ & & & \\
\hline \multirow{2}{*}{ 6電压法 } & $\begin{aligned} & R_{c}\left(e_{i}-e_{i}-E+e_{n}\right)\left[2\left(e_{1}-e_{s}-E\right)\left(e_{s}-e_{s}-E\right)+\right. \\
R_{1}= & \left.e_{n}\left(e_{1}-e_{1}+e_{s}-e_{6}-2 E\right)\right]\end{aligned}$ & \multirow{2}{*}{$\begin{array}{c}\left(R_{l}\right)=\frac{2 R_{c}\left(e_{1}-e_{2}-E\right)\left(e_{3}-e_{1}-E\right)\left(e_{5}-e_{6}-E\right)}{E\left(e_{3}-e_{4}+e_{2}-e_{1}\right)\left(e_{5}-e_{0}-E\right)-} \\
\left(e_{3}-e_{4}-E\right)\left(e_{1}-e_{2}-E\right)\left(e_{5}-e_{6}\right)\end{array}$} & \multirow{2}{*}{$\beta \div 1$} & \multirow{2}{*}{$\beta \doteqdot 1$} \\
\hline & $\begin{array}{l}\left(E-e_{n}\right)\left(e_{5}-e_{4}+e_{2}-e_{1}\right)\left(e_{5}-e_{5}-E+e_{n}\right)- \\
\left(e_{1}-e_{1}-E+e_{n}\right)\left(e_{1}-e_{2}-E+e_{n}\right)\left(e_{5}-e_{b}\right)\end{array}$ & & & \\
\hline
\end{tabular}




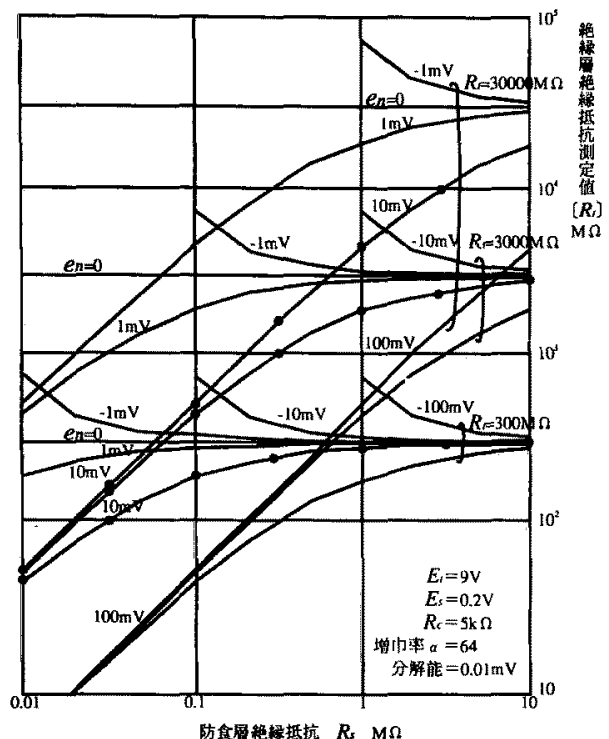

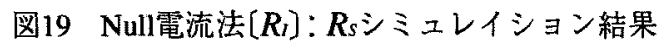

Fig.19. Simulation result on $\left[R_{I}\right]$ vs. $R s$ relationship by Null current method

〈4-1〉測定系の接地を変電所外より持込むこれは最 も簡単に実用化して実効をあげ得るものである。変電所フ エンスより少くとも $20 \mathrm{~m}$ 以上離れていて、地下埋設物が存 在せず、いかにも中立の大地電位を拾えると思われる地点 で接地工事を施し、それからの接地線を測定装置まで持込 む。変電所フェンス下を通る地帯では引込み接地線に耐圧 養生を施す。変電所接地との間にはアレスタを設置し、か つ測定時以外は測定系の接地は変電所接地に戻しておくの が良い。

本法の欠点は、防食層絶縁不良が変電所内で発生してい る場合には逆効果となりか格ないことであるが、それでも 現方式で、大部分の防食層絶縁不良は変電所外で発生して いることと比較するなれば、格段の改良といえる。

〈4.2〉変電所外よりの引込み接地と变電所接地の両方を 交互に使って2回の測定を行ない、データを選別する

これは上記方式の改良案であり、実際には自動化された 測定システムでないと実現が困難であるが、理想的な方式 といえる。

接地を切替えての2回の測定で得られた結果のうち[R]の 高い值を採用するとか、低い值を採用するといった選別方 法をとるのではなく、1点のデータを構成するもととなった 多数のサンプリング測定值の標準偏差を求めて、その小な る方の接地方式で得られた測定值をもって、不定雑音電圧 $e_{n}$ の少ない環境で得られた真に近い測定值であるとするの である。(5)

〈4.3〉フィルタ要素からチョークコイルを排し、抵抗に 替える 測定系の入力部には交流分減衰の目的をもって 低域瀘波器の扦入が実用上不可欠である。その直列要素と して従来はチョークコイル $(30 \sim 100 \mathrm{H})$ を使用して来た。チ ヨークコイルはその内部抵抗が低い点を買って来たのであ

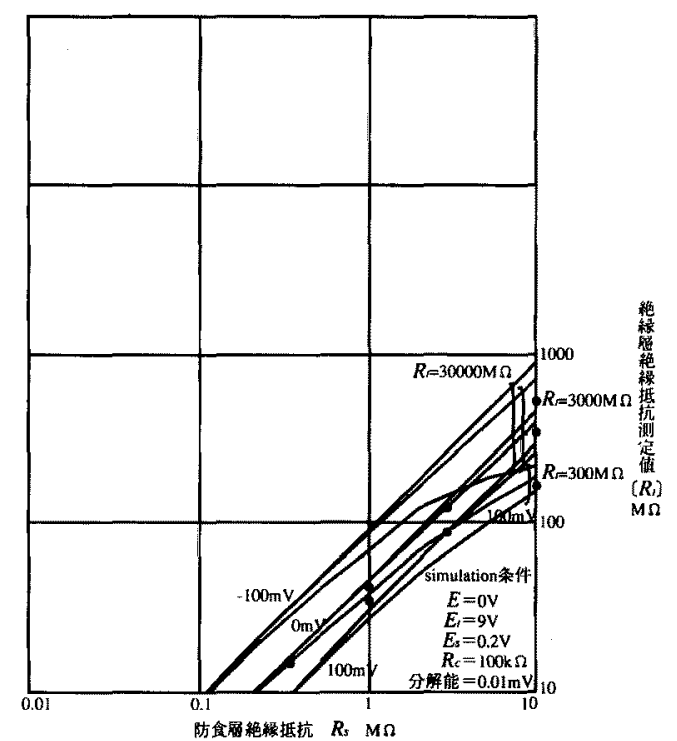

図20 2電圧法 $\left[R_{I}\right]: R_{s}$ シミュレイション結果

Fig.20. Simulation result on $[R]$ vs. $R s$ relationship by 2 voltage method

るが、直流変動入力の侵入に対して微分効果により雑音電 圧の增幅効果を生じていることが経験的に明らかとなった ので、今ではチョークコイルの使用を止め、 $10 \mathrm{k} \Omega$ 程度の 抵抗を直列要素としている。その効果の1例を図 21 に示す。
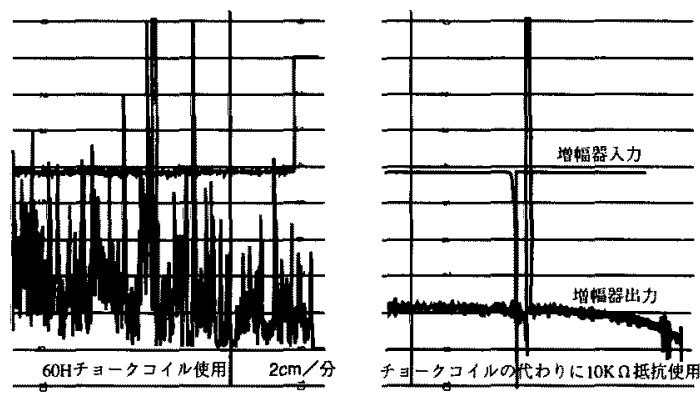

図21チョークコイルを抵抗に代えた雑音電圧低隇効果

Fig.21. Noise reduction effect by changing filter element $L$ to $R$

〈4.4〉接点フラッシングの採用 測定系回路内には、 ケーブル切替えに用いる強電用電磁接触器や、その他の補 助りレーの接点の複数が不可避的に直列に存在する。その 接点を通じて $\mu \mathrm{A} 、 \mathrm{nA}$ クラスの電流を通さなければならぬ のであるが、これらの接点は環境条件により絶縁被膜を形 成することがあり、その場合は測定値の激しい変動として あらわれ、測定が不可能となるほどの重大な支障を生じる。

この現象に対しては各ケーブル切替えスイッチの動作ご とに、自動的に直列全接点に1 2秒間、 $100 \mathrm{~mA}$ 程度の直流 電流を流した後に測定を開始することで、劇的な改善効果 をあげ得ることが判った。今ではこの接点フラッシングは 必須の手段となっている。効果の1例を図22に示す。(4) 


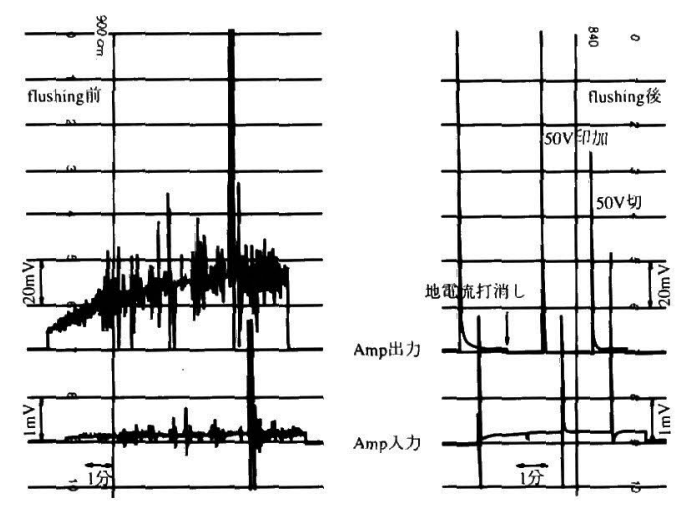

図22 測定系接点フラッシングによる雑音電圧低減効果

Fig.22. Noise reduction effect by current flushing through faulty contacts

\section{5. むすび}

直流重畳法で知られるケーブル活線下絶縁抵抗測定の代 表的な6手法について個々に簡単な解説をまず行なった。

ついで絶縁層絶縁抵抗の測定に影響を与える、不定雑音 電圧 $e_{n}$ の発生源、測定系への侵入経路について調査検討結 果を示し、その影響状況につき数式的解析を行なって、各 手法について $n$ を折込んだ新計算式を提示した。

その結果各手法は $e n$ の影響する程度によって $(\mathrm{A}) \sim(\mathrm{C})$ の3 つのグループに別けられることになった。

enの影響が極めて少ないとされた $(\mathrm{A})$ のグループの4電圧 法、6電圧法は現実のフィールドでの使用が不可能視され、 アイデア倒れの感がある。

$e_{n}$ のみなら゙ $E_{\text {や }} E_{s}$ み影響まで受ける $(\mathrm{c})$ グループの2電 圧法は、直流信号電圧を高压系統に仕掛ける必要が無い利 点を生かして、スクリーニングテスト的に用いることが考 えられるが、それでも絶縁良好のケーブルを不良であると 誤認する危険性が高いので、実用性は疑問である。

残る(B)グループは前記 2 グループの中間的存在で、 $e_{n}$ の みがR,とRsの比 $K に よ り$ 増幅された形でR，測定値に影響を与 える。しかしながら現実にフィールドで実用性を持つのは このグループのNull電流法、3電圧法である。Null電圧法は 手動バラックセットで用いるのに適している。

最後に不定雑音電圧enの影響をできるだけ排除する手段 として、変電所外よりの接地の持込みと、両接地を交互に 使ってデータの偏差值の小なる方の測定値を選ぶ方法を提 案した。さらに測定系自体の雑音電圧発生源の排除策とし て、チョークコイルに代える抵抗の使用と、測定の都度の 接点事前フラッシングの効果の大なることを提示した。

ケーブル活線下絶縁測定技術の向上に本論文が裨益する ところがあれば、筆者の喜びこれに過ぎるはない。

本論文のかげに東 勇夫氏の御努力があったことを特筆 して、ここに謝意を表する。

(平成7年9月22日受付, 同7年12月22日再受付)

\section{文献}

（1）中山忠晴：「ケーブル活線下絶縁監視装置（OLCM） の実用化について」、電気学会絶縁材料研究会資料、 EIM-86-34, 1986

(2) T. Nakayama : "ON-LINE CABLE MONITOR DEVELOPED IN JAPAN", IEEE Transactions on Power Delivery, Vol. 6, NO. 4, October 1991

（3）中山忠晴：「活線下ケーブル絶縁監視方法」、公開特 許公報＼cjkstart昭59-125075、特願昭57-234791、出願昭57(1982) 12月29日

（4）中山忠晴：「微少電流測定装置および方法」、公開特 許公報 平6-94758、特願平3-305936、出願平3（1991） 11月21日

（5）中山忠晴：「AOLCMによる高圧ケーブル監視技術の 向上」、'91設備診断技術シンポジウム、日本プラント メンテナンス協会

中山 忠晴 （正員）1926年2月22日生まれ。43年12月大

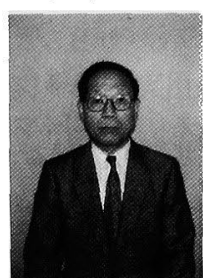
阪市立都島工業学校電気科卒業。44年1月住 友電気工業 (株) 入社。絶縁材料、低ガス圧 ケーブル、パイプタイプケーブルの開発研 究に従事。68年以降ケーブル保守関係機器 開発に従事。79年住電エンジニアリング(株) 出向。88年専務取締役。現在同社顧問。 